\title{
Efficacy of Some New Insecticides against Brinjal Shoot and Fruit Borer Leucinodes orbonalis Guenee
}

\author{
M. Reshma* and P.K. Behera \\ Department of Entomology, OUAT, Bhubaneswar, India \\ *Corresponding author
}

\section{A B S T R A C T}

\begin{tabular}{|l|}
\hline K e y w o r d s \\
$\begin{array}{l}\text { Brinjal, Insecticides, Fruit } \\
\text { and shoot borer, } \\
\text { Infestation }\end{array}$ \\
\hline Article Info \\
\hline $\begin{array}{l}\text { Accepted: } \\
10 \text { April } 2018 \\
\text { Available Online: } \\
10 \text { May } 2018\end{array}$ \\
\hline
\end{tabular}

\section{Introduction}

Brinjal is an important crop grown in all the seasons. Due to its nutritive value, consisting of minerals like iron, phosphorous, calcium and vitamins like $\mathrm{A}, \mathrm{B}$ and $\mathrm{C}$, unripe fruits are used primarily as vegetable in the country. It is also used as a raw material in pickle making (Singh, 1963) and as an excellent remedy for those suffering from liver complaints. In 2013, global production of eggplants was 49.4 million tonnes (FAOSTAT, 2013). More than $1,600,000$ hectares $(4,000,000$ acres $)$ are devoted to the cultivation of eggplants in the world. India constitutes $27 \%$ of world total (FAOSTAT, 2012). In India, Brinjal shoot and fruit borer (BFSB) is considered the most destructive pest causing huge losses in brinjal
(Patil, 1990). It causes severe damage in South Asia (Thapa, 2010), where yield losses may reach up to 85 to 90 percent (Misra, 2008; Jagginavar et al., 2009). The larvae bore into tender shoots at the vegetative stage, flower and fruit (CABI, 2007).

Flower infestation is very rare, but infested flowers cannot produce fruit (Alam et al., 2006). But once fruit setting has been initiated, shoot infestations become negligible (Kumar and Dharmendra, 2013) or completely disappear (Naqvi et al., 2009).

The present study was carried out to evaluate the efficacy of different insecticides to find the best practice if insecticides have to be applied for management of the borer. 
Materials and Methods

The study was conducted at All India Coordinated project on vegetable crops, Bhubaneswar $\left(20^{\circ} 15^{\prime} \mathrm{N}\right.$ and $\left.850 \quad 52^{\prime} \mathrm{E}\right)$ during kharif 2016 and rabi 2017. Brinjal variety "Utkalanushree" was used in kharif 2016 for experimental purpose. Utkal Anushree is a national release from OUAT. This cultivar is resistant against bacterial blight of brinjal and other sucking pests. The experiment was carried out in randomized complete block design with three replications and seven treatments. Seedlings of three to four leaf stage was transplanted into the field for kharif and rabi trail. Each subplot is measured $8.1 \mathrm{~m} 2(2.7 \mathrm{~m} \mathrm{X} 3 \mathrm{~m})$. Each sub-plot was separated from each other by bunds. Light irrigation was given right after transplanting. The experiment plot was ploughed thoroughly. Farm Yard manure (FYM) @ 5 tonnes /ha was incorporated into the soil at the time of final land preparation.

A spacing of $60 \times 45 \mathrm{~cm}$ is maintained. Chemical fertilizers were applied @ 120:50:70kg of N: P2O5: K2O per hectare. Full dose of P2O5 and 20\% K2O and Nitrogen are applied as basal dose. Rest of the fertilizers applied as two top dressings at an interval of 3 weeks. Three insecticide sprays were applied at 20 days intervals using a knapsack sprayer. Water was applied to control plots when insecticides were sprayed. Treatments were applied to the whole plots and data was recorded

For recording shoot infestation, healthy and infested shoots were counted on 10 randomly selected plants. Shoot damage caused by $L$. orbonalis was identified by wilting of the terminal shoots in vegetative stage. Data were recorded one day before spray and three, seven and fourteen days after treatment. Percent shoot infestation was calculated by using the following formula:
No. of infested shoots

Percent Shoot damage = ------------------ x 100

Total no. of shoots

Data were analyzed by using analysis of variance (ANOVA) and mean separation was done by calculating least significance difference at $\mathrm{P}=0.05$.

\section{Results and Discussion}

The attack of $L$. orbonalis (shoot infestation) was recorded only at 7 days in kharif after first spray, as there was no infestation by $L$. orbonalis (shoot and fruitborer) prior to 7 days. At 7 DAS, lowest shoot infestation (\%) was observed in rynaxypyr (7.77), which was at par with emamectin benzoate (8.20) and flubendiamide (8.55). Highest shoot damage (14.2\%) was recorded in untreated control which was significantly different from other treatments.

At 14 DAS, lowest shoot damage (\%) was recorded in rynaxypyr (4.50) which was at par with flubendiamide (5.20) and emamectin benzoate (2.58). Moreover, all these insecticides were significantly different from untreated control (16.30). During the post spray period, highest $\%$ reduction over control was recorded in rynaxypyr (59.80), followed by flubendiamide (54.95).

The lowest $\%$ reduction over control was recorded in spinosad (42.49). All the insecticides were significantly superior to untreated control (11.93). At 7 DAS, the lowest shoot damage $(2.10 \%)$ was recorded in case of rynaxypyr which was at par with flubendiamide $(2.32 \%)$, spinosad $(2.46 \%)$ and emamectin benzoate $(2.61 \%)$.

However, thiamethoxam $(3.85 \%)$ found to be least effective among the test insecticides. Highest infestation of shoot was observed in untreated control $(11.92 \%)$ during summer (Table 1-3). 
Table.1 Effect of Insecticidal treatments on shoot infestation (\%) by L. orbonalis during kharif 2016 and Summer 2017 at Bhubaneswar (1st Spray)

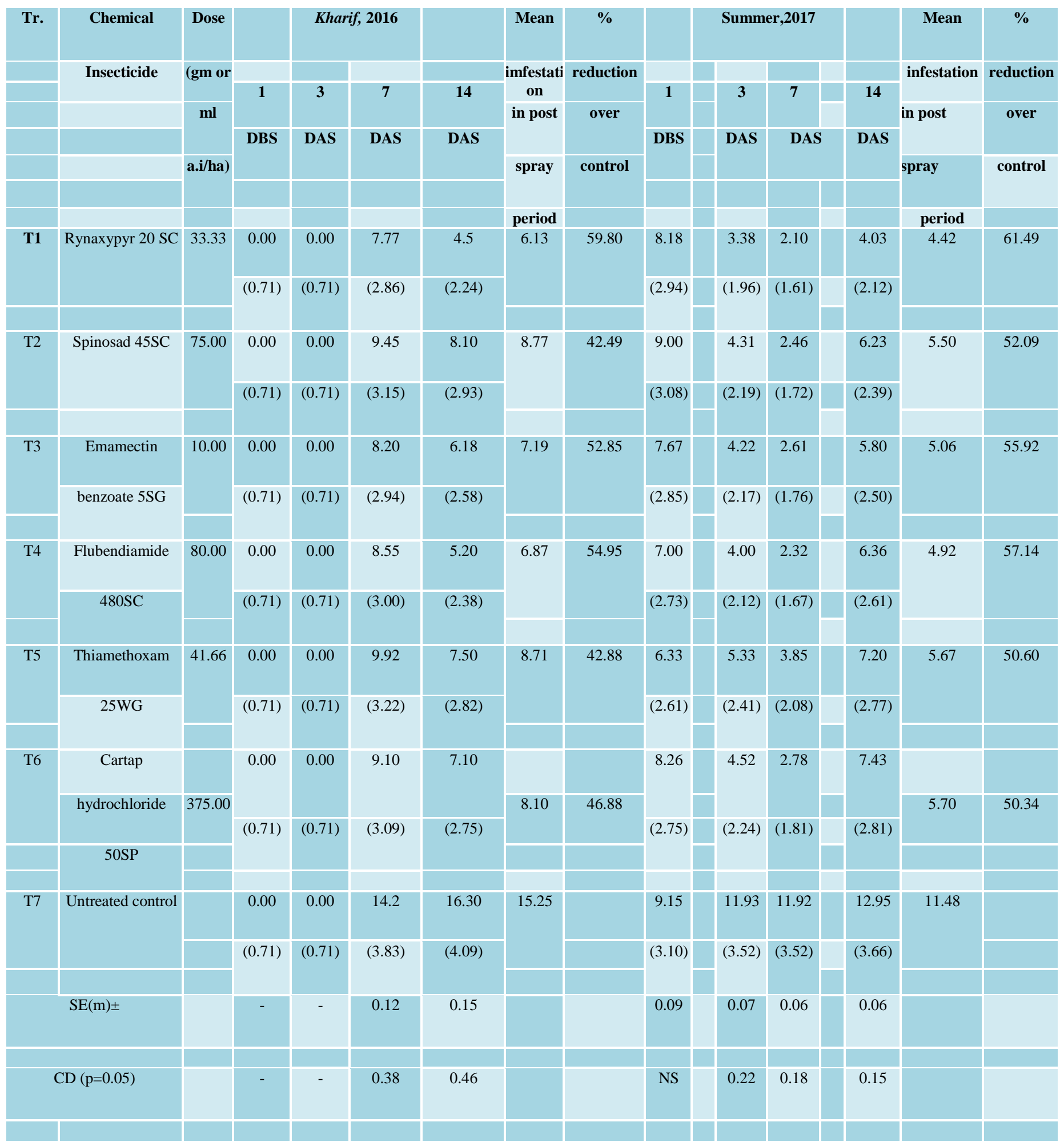


Table.2 Effect of insecticidal treatments on shoot infestation (\%) by L. orbonalis during kharif 2016 and Summer 2017 at Bhubaneswar $\left(2^{\text {nd }}\right.$ Spray $)$

\begin{tabular}{|c|c|c|c|c|c|c|c|c|c|c|c|c|c|c|}
\hline \multirow[t]{2}{*}{ Tr. } & \multirow{2}{*}{$\begin{array}{l}\text { Chemical } \\
\text { Insecticide }\end{array}$} & \multirow{2}{*}{$\begin{array}{l}\text { Dose } \\
\text { (gm or }\end{array}$} & & \multicolumn{2}{|c|}{ Kharif,2016 } & & \multirow{2}{*}{$\begin{array}{c}\text { Mean } \\
\text { infestation }\end{array}$} & \multirow{2}{*}{$\begin{array}{c}\% \\
\text { reduction }\end{array}$} & & \multicolumn{2}{|c|}{ Summer,2017 } & & \multirow{2}{*}{$\begin{array}{c}\text { Mean } \\
\text { infestation }\end{array}$} & \multirow{2}{*}{$\begin{array}{c}\% \\
\text { reduction }\end{array}$} \\
\hline & & & & & & & & & & & & & & \\
\hline & & ml & 1 & 3 & 7 & 14 & in post & over & 1 & 3 & 7 & 14 & in post & over \\
\hline & & a.i/ha) & DBS & DAS & DAS & DAS & spray & control & DBS & DAS & DAS & DAS & spray & control \\
\hline & & & & & & & period & & & & & & period & \\
\hline \multirow[t]{2}{*}{ T1 } & \multirow[t]{2}{*}{ Rynaxypyr 20 SC } & \multirow[t]{2}{*}{33.33} & 6.45 & 5.23 & 4.36 & 2.32 & \multirow[t]{2}{*}{4.59} & \multirow[t]{2}{*}{61.20} & 13.72 & 6.30 & 4.81 & 2.89 & \multirow[t]{2}{*}{4.66} & \multirow[t]{2}{*}{73.79} \\
\hline & & & $(2.63)$ & $(2.39)$ & $(2.20)$ & $(2.15)$ & & & $(3.77)$ & $(2.60)$ & $(2.30)$ & (1.84) & & \\
\hline \multirow[t]{2}{*}{$\mathrm{T} 2$} & \multirow[t]{2}{*}{ Spinosad 45SC } & \multirow[t]{2}{*}{75.00} & 6.10 & 5.07 & 4.50 & 3.20 & \multirow[t]{2}{*}{4.71} & \multirow[t]{2}{*}{60.18} & 13.92 & 9.20 & 5.29 & 3.63 & \multirow[t]{2}{*}{6.04} & \multirow[t]{2}{*}{66.02} \\
\hline & & & $(2.56)$ & $(2.36)$ & $(2.23)$ & $(1.92)$ & & & $(3.80)$ & (3.11) & $(1.84)$ & $(2.03)$ & & \\
\hline \multirow[t]{3}{*}{$\mathrm{T} 3$} & \multirow[t]{2}{*}{ Emamectin } & & \multirow[t]{2}{*}{6.00} & 4.23 & \multirow[t]{2}{*}{3.33} & \multirow[t]{2}{*}{3.80} & & & 15.88 & \multirow[t]{2}{*}{6.60} & \multirow[t]{2}{*}{6.52} & 5.20 & & \\
\hline & & 10.00 & & $(2.17)$ & & & 4.35 & 63.22 & (4.04) & & & & 6.10 & 65.69 \\
\hline & benzoate 5SG & & $(2.54)$ & & $(1.95)$ & $(1.96)$ & & & & $(2.66)$ & $(2.64)$ & $(2.38)$ & & \\
\hline $\mathrm{T} 4$ & Flubendiamide & 80.00 & 6.96 & 5.20 & 4.72 & 2.20 & 4.77 & 59.67 & 14.89 & 7.15 & 6.86 & 5.53 & 6.51 & 63.38 \\
\hline & 480SC & & $(2.73)$ & $(2.38)$ & $(2.28)$ & (1.69) & & & $(3.92)$ & $(2.75)$ & $(2.71)$ & $(2.45)$ & & \\
\hline T5 & Thiamethoxam & 41.66 & 7.80 & 6.05 & 5.13 & 4.49 & 5.86 & 50.46 & 15.53 & 9.81 & 5.17 & 4.62 & 6.53 & 63.27 \\
\hline & $25 \mathrm{WG}$ & & $(2.88)$ & $(2.55)$ & $(2.37$ & $(2.23)$ & & & $(4.00)$ & $(3.21)$ & $(2.38)$ & $(2.26)$ & & \\
\hline T6 & Cartap & & 7.93 & 6.55 & 6.00 & 4.23 & & & 16.00 & 7.45 & 8.33 & 6.43 & & \\
\hline & hydrochloride & 375.00 & & & & & 6.17 & 47.84 & & & & & 7.04 & 60.40 \\
\hline & & & $(2.90)$ & $(2.65)$ & $(2.54)$ & $(2.17)$ & & & $(4.06)$ & $(281)$ & $(2.97)$ & $(2.63)$ & & \\
\hline & $50 \mathrm{SP}$ & & & & & & & & & & & & & \\
\hline $\mathrm{T} 7$ & Untreated control & & 13.75 & 13.20 & 9.73 & 10.65 & 11.83 & & 16.67 & 18.10 & 18.33 & 16.89 & 17.78 & \\
\hline & & & $(3.77)$ & $(3.70)$ & (3.19) & (3.33) & & & $(4.14)$ & $(4.31)$ & (4.33) & $(4.17)$ & & \\
\hline & $\mathrm{SE}(\mathrm{m}) \pm$ & & 0.15 & 0.12 & 0.09 & 0.10 & & & 0.22 & 0.20 & 0.17 & 0.10 & & \\
\hline & $\mathrm{CD}(\mathrm{p}=0.05)$ & & 0.42 & 0.35 & 0.27 & 0.28 & & & NS & 0.59 & 0.51 & 0.30 & & \\
\hline
\end{tabular}


Table.3 Effect of insecticidal treatments on shoot infestation (\%) by L. orbonalis during kharif 2016 and Summer 2017 at Bhubaneswar ( $3^{\text {rd }}$ Spray)

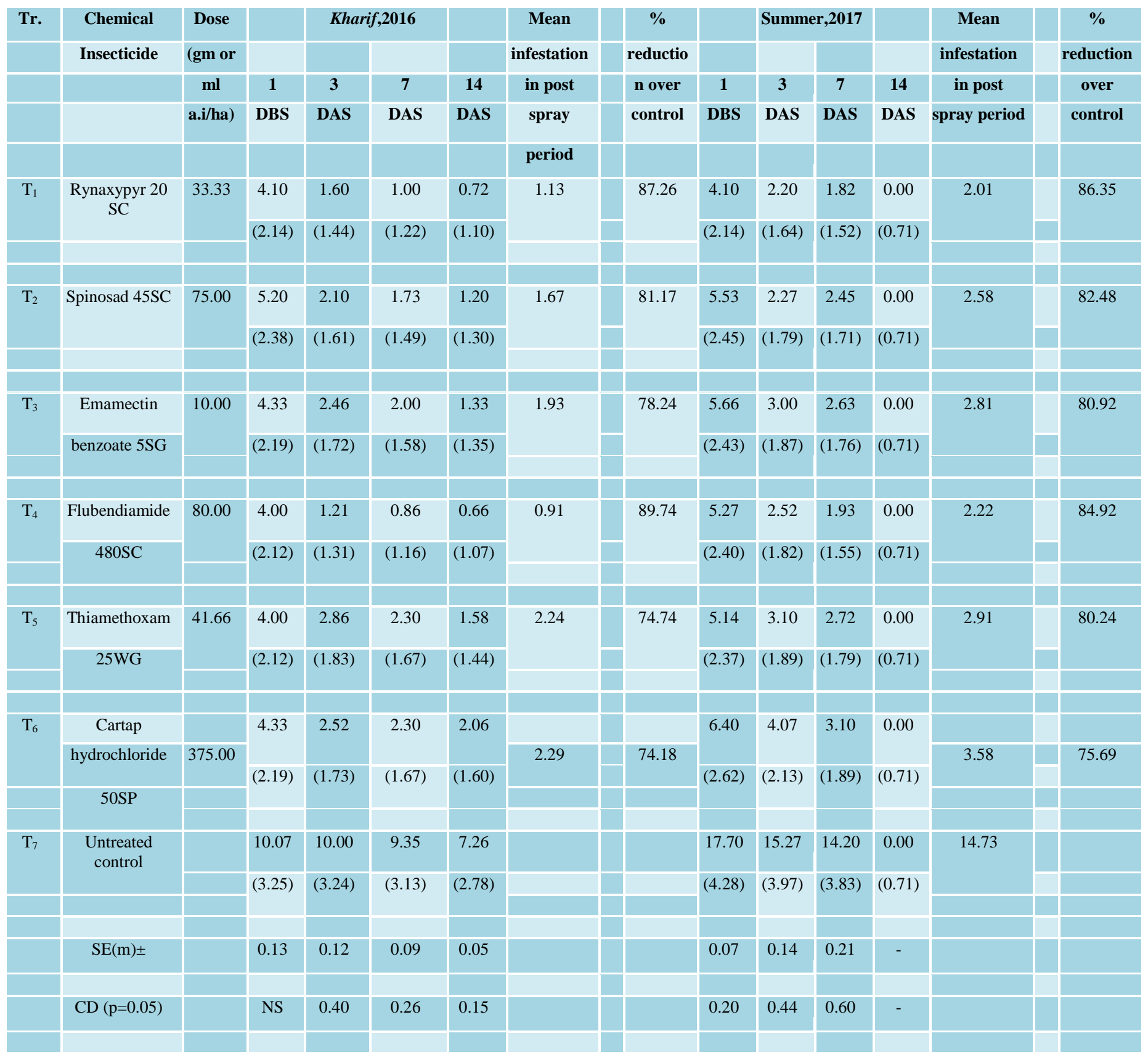

During the post spray period of second spray, highest \% reduction over control was seen in case of rynaxypyr (61.49), followed by flubendiamide (57.14). The lowest \% reduction over control was noted in case of cartap hydrochloride (50.34). At 14 DAS, spinosad, emamectin benzoate and flubendiamide are at par with each other Highest infestation was observed in control $(10.65 \%)$. 1 day before the second spray during summer season, the shoot damage (\%) was found to the tune of 3.77-4.14 in different treatments. 1 day before the second spraying during kharif season, the shoot damage (\%) 
was found to the tune of 6.00-7.93 in different treatments. 1 day before the second spray during summer season, the shoot damage (\%) was found to the tune of 3.77-4.14 in different treatments.

One day before third spray during kharif season, the shoot damage (\%) was limited to 4.00-10.07 in different treatments. During the post spray period, highest reduction percent over control was found in flubendiamide (89.74), followed by 87.26 in rynaxypyr. Lower reduction (\%) over control was obtained in cartap hydrochloride (74.18). 1 day before the third spray, during summer season, shoot damage (\%) was found to the extent of 4.10-17.70 in different treatments. At 3DAS it was that, the shoot damage $\%$ in thiamethoxam (3.10) was found to be at par with rynaxypyr (2.20), spinosad (2.27), flubendiamide (2.52), emamectin benzoate (3.00).

Maximum infested shoot are observed in untreated control (15.27). At 7 DAS, all the treatments are significantly at par with each other and the percent infestation is $14.20 \%$. During the post spray period, highest reduction (\%) over control was founded in rynaxypyr (86.35) followed by (84.92) in case of flubendiamide. After 7 DAS the population was negligible hence it was not recorded. It is concluded that the tested insecticide reduced shoot and fruit infestation in treated as compared to those in untreated plots. For control of shoot infestation, flubendiamide (Belt 48SC) and emamectin benzoate (Timer 1.9EC) were better in both seasons.

The present findings revealed that flubendiamide and rynaxypyr showed up better results in controlling the shoot and fruit damage whereas spinosad and emamectin benzoate gave moderate control and cartap hydrochloride was found to be least effective. Latif et al., (2009 and 2010); Abdullah et al.,
(2014) reported that flubendiamide is used effectively against shoot and fruit borer upto $80 \%$ of shoot infestation. Rajavel et al., (2011); Mandal et al., (2010) concluded that rynaxypyr is effective against eggplant fruit and shoot borer. Deshmukh and Bhamare (2006); Adiroubane and Raghuraman (2008) indicated that spinosad $45 \mathrm{EC}$ was effective in reducing the shoot and fruit borer infestation. Dutta et al., (2007) reported that emamectin benzoate showed moderate level of efficacy providing $62.8 \%$ reduction of brinjal fruit and shoot borer population over control.

\section{References}

Abdullah, Khandakar Shariful Islam, Mahbuba Jahan, and Gopal Das. 2014, Research Article Comparative potency of three insecticides against the infestation of brinjal shoot and fruit borer, Leucinodes orbonalisGuen., Journal of Biosciences,2(6): 364-369.

Adiroubane D and Raghuraman K. 2008. Plant products and microbial formulation in the management of brinjal shoot and fruit borer, Leucinodes orbonalis (Guenee.), Agricultural. Science, 22 (3): 712-713.

Alam, SN, Hossain, M.I, Rouf, F.MA, Jhala, R.C., Patel, M.G, Rath,.LK., Sengupta, A., Baral, K., Shylesha, A.N., Satpathy, S., Shivalingaswamy, T.M., Cork, A. Andtalekar, N.S., 2006.Implementation and promotion of an IPM strategy for control of eggplant fruit and shoot borer in South Asia. Tech. Bull. 36. AVRDC publication number 06-672. AVRDC The World Vegetable Center, Shanhua, Taiwan. Pp. 74

CABI, 2007. Crop protection compendium. CAB International. (Available at: http:// www. cabicompendium.org/cpc).

Deshmukh RM and Bhamare VK. 2006. Field evaluation of some insecticides against brinjal shoot and fruit borer, Leucinodes 
orbonalis Guen. International Journal of Agricultural Sciences, 2(1): 247-249.

Dutta NK, Alam MS, Nasiruddin M, Das AK, and Munmun TS. 2007. Efficacy of some new chemical insecticides against Brinjal Shoot and Fruit Borer (Leucinodes orbonales Guen.), Journal of Subtropical Agricultural Research and Development, 5(3): 301-304.

FAOSTAT FAO. 2012-05-12. Archived from the original on 2015-09-06. Retrieved 2012-05-12.

FAOSTAT. FAO faostat3.fao.org. Retrieved 2016-04-07.

Jagginavar S.B., Sunitha N.D., Biradar A.P. (2009). Bioefficacy of flubendiamide 480SC against brinjal fruit and shoot borer, Leucinodes orbonalis Guen. Karnataka Journal Agricultural Science, 22 (3): 712-713.

Kumar, S. AND Dharmendra, S., 2013. Seasonal incidence and economic losses of brinjal shoot and fruit borer, Leucinodes orbonalis Guenee. Agric. Sci. Digest., 33: 98-103.

Latif MA, Rahman MM and Alam MZ. 2010. Efficacy of nine insecticides against shoot and fruit borer, Leucinodes orbonalis Guenee (Lepidoptera: Pyralidae) in eggplant. Journal of Pest Science, 83(4): 391 - 397.

Latif MA, Rahman MM, Alam MZ and Hussain MM. 2009. Effect of flubendiamide and some other insecticides on arthropod's biodiversity used to control brinjal shoot and fruit borer (Leucinodes orbonalis G.), International Journal of Agriculture Environment and Biotechnology, 2(2): 173-179

Mandal S, Singh NJ, Konar A. 2010.Efficacy of synthetic and botanical insecticide against whitefly (Bemicia tabaci) and shoot and fruit borer (Leucinodes orbonalis) on brinjal (Solanum melongena L.), Journal of Crop Weed, 6(1): 49-51.

Misra HP. 2008. New promising insecticides for the management of brinjal shoot and fruit borer, Leucinodes orbonalis Guenee. Pest Management of Horticulture Ecosystem, 14(2):140-147.

Naqvi, AR., Pareek, BL. and Mitharwal, BS, 2009. Seasonal incidence of shoot and fruit borer, Leucinodes orbonalis Guenee infesting in hyper arid regions of Rajhistan. J. Insect Sci., 22: 195-198.

Rajavel D.S., Mohanraj A, Bharathi K. Efficacy of chlorantraniliprole (Coragen 20SC) against brinjal shoot and fruit borer, Leucinodes orbonalis (Guen.). Pest Management in Horticultural Ecosystems. 17(1): 28-31.

Singh S. Krishnakumar S. and Katyal, S.L. 1963, Fruit culture in India. Indian Council of Agricultural Research, New Delhi, 412 P.

Thapa, R.B., 2010. Integrated management of brinjal fruit and shoot borer, Leucinodes orbonalis Guen: An overview. J. Inst. Agric. Anim. Sci., 30 \& 32: 1- 16.

\section{How to cite this article:}

Reshma, M. and Behera, P.K. 2018. Efficacy of Some New Insecticides against Brinjal Shoot and Fruit Borer Leucinodes orbonalis Guenee. Int.J.Curr.Microbiol.App.Sci. 7(05): 1170-1176. doi: https://doi.org/10.20546/ijcmas.2018.705.142 